\title{
Resemantización de la Imagen de la Santa Muerte en publicaciones de Mina editores: culto, símbolos marianos y feminización
}

Resemantization of the Image of Santa Muerte in Mina editores publications. Cult, Marian symbols and feminization

Azul Kikey Castelli Olvera

Universidad Autónoma del Estado de Hidalgo, Pachuca, México

Pachuca, México

azul_castelli@uaeh.edu.mx

\section{RESUMEN}

El artículo busca analizar la resemantización visual de las imágenes de la Santa Muerte en las publicaciones sobre temas esotéricos de Mina Editores: Mundo Esotérico y Libro Mágico, a través de las categorías de la posmodernidad y la New Age. Para este propósito se realizó un análisis cualitativo de la imagen de las portadas de las revistas utilizando el método indicial propuesto por Carlo Ginzburg considerando elementos de la historia, la semiótica y la posmodernidad a partir de los estudios de Elsa Malvido y Katya Perdigón, Frederic Jameson y Wouter Hanegraaff. Se observa una resemantización de la imagen de la Santa Muerte en las portadas y contenidos de las Revistas Mundo Esotérico y Libro Mágico. Se incluyen elementos medievales, católicos y prehispánicos, que vinculan a esta figura con una visión positiva, desligada de imágenes maléficas o de magia negra, tendiendo a la feminización de la imagen que traspone el culto de esta santa relacionándolo con la maternidad, en una transmutación de elementos marianos. Como parte de las conclusiones se observa un proceso de resemantización y fagotización en la imagen de la Santa Muerte, la cual se va modificando a través del tiempo pasando de una representación masculinizada y de esqueleto seco, a una más tendiente a la feminización corporal y al culto de las vírgenes.

Palabras clave: Imagen; religión; representación visual; medios de comunicación de masas; muerte.

\section{ABSTRACT}

The article seeks to analyze the visual resemantization of the images of the Holy Death in the publications on esoteric subjects of Mina Editores: Mundo Esotérico and Libro Mágico, through the categories of post-modernity and New Age. For this purpose, a qualitative analysis of the image of the magazine covers was carried out using the indicial method proposed by Carlo Ginzburg considering elements of history, semiotics, and postmodernity from the studies of Elsa Malvido and Katya Perdigón, Frederic Jameson and Wouter Hanegraaff. A resemantization of the image of the Holy Death is observed in the covers and contents of the magazines Mundo Esotérico and Libro Mágico. Medieval, Catholic, and pre-Hispanic elements are included, which link this figure with a positive vision, detached from malefic images or black magic, tending to the feminization of the image that transposes the cult of this saint relating it to motherhood, in a transmutation of Marian elements. As part of the conclusions, a process of re-semantization and phagocytization can be observed in the image of the Holy Death, which is modified over time, going from a masculinized representation with a dry skeleton to one that tends more towards the feminization of the body and the cult of virgins.

Keywords: Image, religion, visual representation, mass media, death. 


\section{INTRODUCCIÓN}

El culto a la muerte no es privativo de un sólo país u época, se pueden encontrar registros y representaciones desde periodos muy antiguos, la constante en todos ha sido, eso sí, la importancia que ha tenido en todas las culturas.

En México se encuentran registros prehispánicos del culto a la muerte como una deidad. Esta práctica se hibridó con las representaciones visuales católicas medievales de la muerte, utilizadas para evangelizar durante la colonia y con diversos procesos históricos subsiguientes. Lo anterior, dio origen a un culto marginal que pervivió a través de los siglos como una expresión de la religiosidad popular y que, al encontrarse con las rupturas de la posmodernidad y la reinterpretación de la espiritualidad de la New Age, dio origen a un nuevo culto que fluctúa entre lo católico, lo pagano y fagocita con facilidad figuras, prácticas y rituales de otras religiones, en donde la figura central es un personaje denominado: La Santa Muerte.

El origen de este culto no es específico, algunos lo ubican en Veracruz, Zacatecas, Oaxaca y otros en Hidalgo (Kristensen, 2014). Las historias relacionan el surgimiento de una figura esquelética, que se apareció a curanderos de estos estados y que empezó a realizar milagros a quienes le rindieran culto. En un principio, el culto se relacionó con grupos marginales como delincuentes, prostitutas, y policías. Sin embargo, en la actualidad, el grupo de creyentes es muchísimo más amplio y no se relaciona con actividades delictivas, únicamente (Argyriadis, 2014).

La representación más usual dentro de este culto es el esqueleto seco vistiendo sayal de fraile, vestido de novia o de virgen. El culto tiene características que coinciden con las religiones populares y es altamente individualista, por lo que no se identifica una sola fecha para su festejo, las oraciones difieren dependiendo de las peticiones y muestran una amplia similitud con las católicas. Los altares también son diversos y se ubican en calles, esquinas, o dentro de comercios y hogares.

Las muestras de devoción van desde exvotos, canciones, procesiones, altares, ropajes, velaciones, etc. Este culto se ve permeado por los medios de comunicación y a finales de la década de los noventas ${ }^{1}$ y del 2000, proliferaron publicaciones periódicas sobre el tema, tal y como se observa en los productos analizados en este trabajo.

El fenómeno religioso y cultural de la Santa Muerte ha sido estudiado desde lo antropológico por autores como Flores (2008), Lara Mireles (2008), Castells-Ballarin (2008), Argyriadis (2014), Gaytán (2008), Yllescas Illescas (2013), Kristensen (2014, 2015, 2019), Huffschmid (2012), Fragoso (2011), entre otros. Estos estudios se centran sobre todo en los creyentes, en sus representaciones e imaginarios así como en sus prácticas, rezos y ceremonias, recuperados a través de la observación, la entrevista o la encuesta. Otra vertiente de estudio parte de la historia y la restauración donde Perdigón (2008) y Malvido (2005) han realizado estudios sobre la relación simbólica de la imagen y representación de la Santa Muerte con otras representaciones y sobre la influencia de la imagen medieval de la muerte y las danzas macabras en la efigie actual de la Santa Muerte.

Partiendo de lo anterior se observa que los estudios de la Santa Muerte han sido abordados sobre todo desde lo antropológico y desde la historia, pero no desde la construcción y modificación de la imagen a través de los medios, elemento preponderante en la época posmoderna y relacionada directamente con la globalización y el movimiento religioso de la New Age. Frente a esto, en este trabajo se presenta un análisis de la resemantización ${ }^{2}$ de la imagen de la Santa Muerte en las portadas y contenidos de las revistas Mundo esotérico y Libro Mágico, que fueron impresas en la década de los noventa del siglo pasado. Para esto se parte de una metodología cualitativa interpretativa y se centra en un objeto de estudio específico para analizar a profundidad.

$1 \quad$ En los años 90 del pasado siglo (...) y con un auge extremo y nunca contemplado de la inseguridad y las violencias cotidianas en el Distrito Federal, es cuando el culto de la Santa Muerte "sale" (...) y toma con sus imágenes y objetos el ámbito público: Mercados, calles, cuerpos(...), medios de comunicación e industrias culturales(...) (Flores, 2008, pág. 58).

2 Categoría que se aborda en el apartado metodológico más adelante. 


\subsection{Mina Editores, Mundo Esotérico y Libro Mágico}

Mina Editores es un grupo editorial que desde 1962 publica una serie de productos editoriales, alcanzando los 45 títulos en más de 58 años de permanencia en el mercado. La visión de la editorial es crear espacios de lectura amena y diversa para satisfacer las necesidades de entretenimiento e información de los lectores mexicanos. La oferta editorial de Mina editores se fue ampliando a lo largo de los años y el alcance geográfico de la misma también, llegando a publicar en Estados Unidos y Centroamérica. La diversidad de títulos abarca una multiplicidad de públicos que van desde niños, adolescentes, jóvenes, amas de casa, fanáticos del manga, etc. (Fig. 1).

Figura 1. Portadas de productos editoriales de Mina Editores

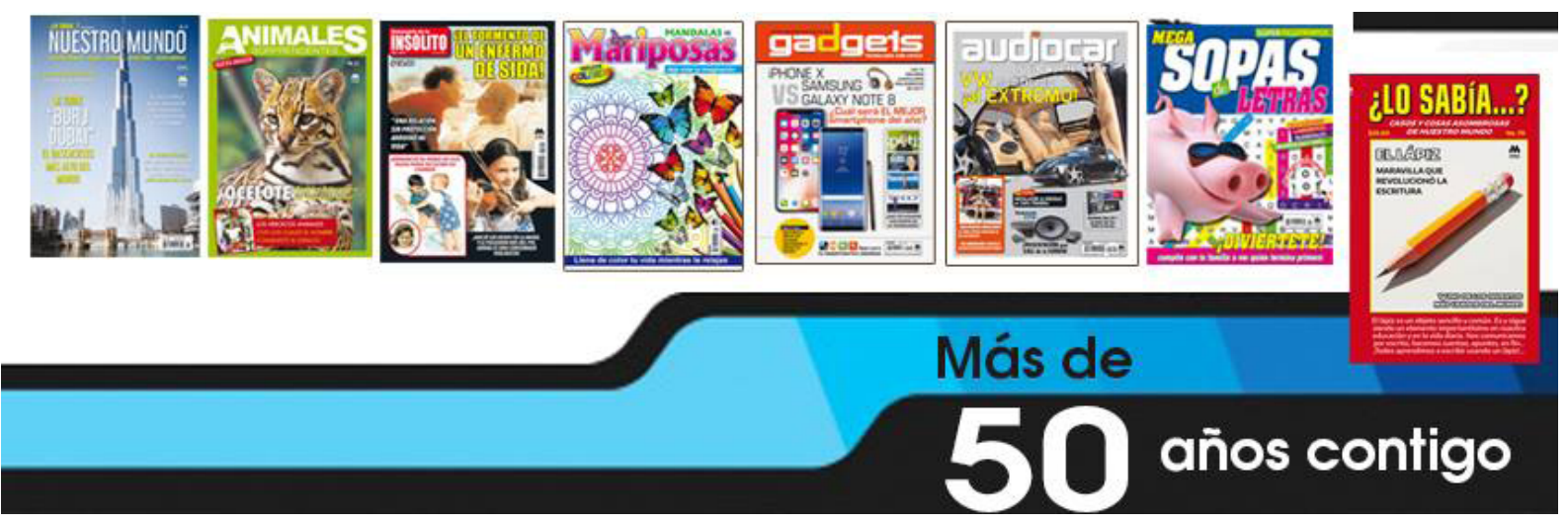

Ejemplo de publicaciones Mina editores (Mina editores, 2018)

Sus publicaciones según su contenido y target se dividen en 6 bloques, los cuales se detallan a continuación (Fig. 2):

Figura 2. Target, editorial Mina

\begin{tabular}{|c|c|}
\hline MIINA GAMES & MINA MIX \\
\hline Master Player & A ventura de Vaqueros \\
\hline N-World & Balnearios y Parques recreativos \\
\hline PSM2 & Cartas de Combate \\
\hline Tips y Trucos & Calcomanias de moda \\
\hline Tips y Trucos Multiplataformas & Calcomanias de Moda Especial \\
\hline XB Player & Colección Mina \\
\hline MMNA COMHCS & Eventos y Ceremonias $X V$ anos \\
\hline Comic Zone & Eventos y Ceremonias especial \\
\hline Mad & Gadgets \\
\hline Otaku & Graffiti Arte Popular \\
\hline Especiat Otaku & H y M serie Grandes Figuras de la Lucha Libre \\
\hline Desde Japón & Historia Semanal de Amor y Pasión \\
\hline Virtual Kid's & Historia de Migrantes \\
\hline Virtual Kid's Edición de Lujo & Mega Revista \\
\hline Virtual Kid's Especial & Mega Revista Especia1 \\
\hline Calcomanias de Moda Especial & Semanario de lo Insólito \\
\hline Virtual Kid's Me ga Revista & Semanario de to Insólito especial \\
\hline Virtual Kid's Shojo & Tatuajes y Perforaciones \\
\hline MIINA HEALTH & MINA MYSTIC \\
\hline American Health \& Fitness & Devoción a la Santa Mverte \\
\hline Especial de Medicina & Enciclopedia Esotérica Especial y Nuevo Mundo \\
\hline Jugos y Licuados & esotérico \\
\hline MIINA CAR & MINA COMICS \\
\hline Avdio Car & Comic Zone \\
\hline Audio Car Especial & Mad \\
\hline Car Audio & Otaku \\
\hline Chevyman ia & Especial O taks \\
\hline Curvas Serie Biker & Desde Japón \\
\hline Curvas Serie Pick Up & Virtual Kid's \\
\hline Import Tuner & Virtual Kid's Edición de Lujo \\
\hline Mundo Volkwa gen & Virtual Kid's Especial \\
\hline Muscle Car's & Calcomanias de Moda Especial \\
\hline Curvas Serie Mustang & Virtual Kid's Mega Revista \\
\hline Tuning Car & Virtual Kid's Shojo \\
\hline \multicolumn{2}{|l|}{ Vochomania } \\
\hline \multicolumn{2}{|l|}{ Vochomania Clásic œs } \\
\hline \multicolumn{2}{|c|}{ Elaboración propia con en el sitio oficial de Mina Editores (Mina editores, 2018) } \\
\hline
\end{tabular}

Elaboración propia con en el sitio oficial de Mina Editores (Mina editores, 2018) 
Las revistas en las que se centra este estudio son Mundo Esotérico y El Libro Mágico. La primera se publicó a partir de 1996 y abarcó cuestiones de brujería, chamanismo, cristianismo, culto a la Santa Muerte, esoterismo, rituales de diversa índole, etc. (Fig. 3). De la segunda, si bien no se encontraron registros, los datos que vienen en la publicación parecen indicar que eran publicaciones mensuales, temáticas e incluían obsequios como imágenes para altares o estampas, las portadas eran a color, en papel couché, con una medida de $18 \mathrm{~cm} \times 14 \mathrm{~cm}$ (Fig. 4).

Figura 3. Revista Mundo Esotérico número 72

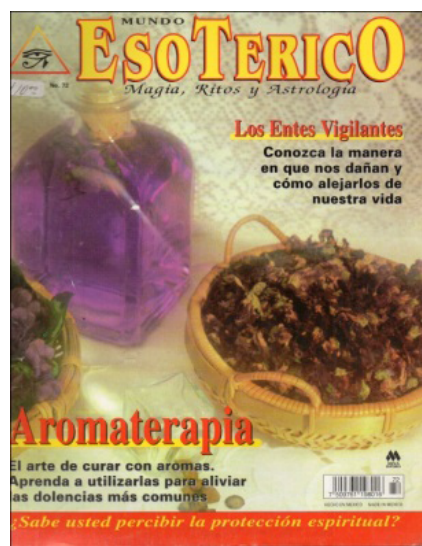

Portada de la Revista Mundo Esotérico número 72 (Mina Editores)

Figura 4. El libro mágico

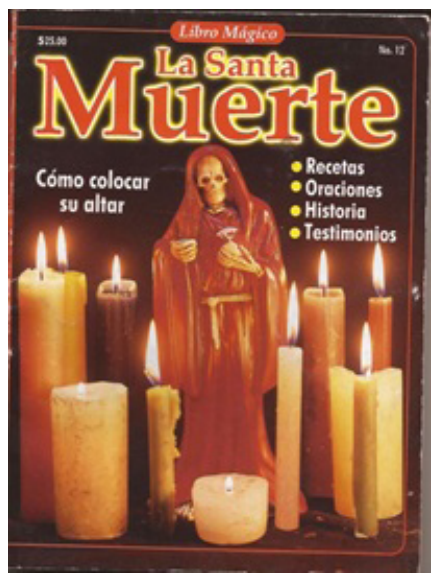

Portada de la Revista Libro Mágico (Mina editores, 2001)

Las portadas de Mundo Esotérico tienen una medida de $27 \times 21$ centímetros y están impresas a color, en la parte superior se ubica el nombre completo, precio, número y logo de la revista, el cual es un símbolo egipcio que representa el ojo de Horus. El resto de la revista integra diferentes elementos visuales que corresponden a distintas religiones que coexisten entre sí como una expresión de la religiosidad popular, incidida por la posmodernidad y la New Age ${ }^{3}$ que retoma retazos de tradiciones exotizadas como signo de la globalización cultural, que tiende a la universalización de religiones históricas con el esoterismo, el

\footnotetext{
3 La New Age tuvo gran visibilidad durante las décadas de 1980 y 1990 en las sociedades occidentales, por ello, es en este periodo en el que se registra un gran número de representaciones visuales de este movimiento. Sin embargo, pese a que su aparición mediática es relativamente reciente, esta nueva religiosidad tiene sus orígenes en el esoterismo occidental de finales del siglo XIX, cuyos vestigios se pueden trazar hasta el Renacimiento tardío, pero tuvo gran auge y enfrentó un proceso de secularización a finales del siglo antepasado, donde se le denominó ocultismo (Hanegraaff, 1999).

El ocultismo fue retomado por el movimiento de New Age que emergió durante la década de los setenta para consolidarse, como ya se mencionó, en las siguientes dos décadas. Durante este periodo se habló de este movimiento considerándolo como una alternativa contra la cultura dominante, especialmente en contra de las prácticas que conciernen a la espiritualidad (Hanegraaff, 1996), conformándose como una ruptura sin precedentes con lo que se conoce como religión, la New Age es un fenómeno nuevo derivado del esoterismo y el ocultismo, y puede definirse como una religión secular basada en un simbolismo privado, es decir, un forma de esoterismo secularizado, donde las imágenes e historias religiosas funcionan fuera del su contexto original (Hanegraaff, 1999).
} 
nativismo y la pseudociencia (De la Torre, 2012).

Estas expresiones, aparecidas en las revistas Mundo Esotérico y El Libro Mágico, encontrarán el espacio ideal para proliferar en las rupturas propias de la posmodernidad, que Jameson (1991) ubica a finales de los años cincuenta o principios de los sesenta y cuyas características son: milenarismo invertido, donde las premoniciones catastróficas o apocalípticas son sustituidas por la sensación de final de una época, ideología, arte, religión, etc.; así como la crisis del leninismo o fin del estado de bienestar, una nueva superficialidad, el debilitamiento de la historia y todo un subsuelo emocional, que derivó en una búsqueda de nuevas espiritualidades y religiosidades.

Todo esto se dará dentro de un tipo de sociedad en específico, la llamada por Bell (citado por Jameson, 1991) sociedad postindustrial, también llamada sociedad de consumo, sociedad de los medias, sociedad de la información o sociedad electrónica o de la alta tecnología, y los productos mediáticos y culturales de la misma se verán permeados por las características de este periodo.

Como parte del surgimiento y visibilización de esta diversidad religiosa, durante la década de los noventa, se observó, como ya se mencionó en párrafos anteriores, la aparición pública del culto a la Santa Muerte. Esta figura y sus devotos poblaron el espacio mediático a inicios de este periodo, sobre todo en las secciones de nota roja, donde se exacerbaban historias macabras de cultos satánicos, en los que proliferaban los sacrificios humanos. Dichas narrativas fueron retomadas por los públicos y reformuladas de manera positiva (Argyriadis, 2014), este cambio y resemantización se observa de igual manera a nivel mediático con una serie de publicaciones, entre las que se encuentran la Revista Mundo Esotérico y El libro mágico.

\section{MÉTODOLOGÍA}

La editorial Mina editores fue una de las primeras publicaciones masivas en las que apareció la imagen de la Santa de manera positiva. En este trabajo se analizan 8 imágenes seleccionadas de 3 ejemplares de la revista Mundo Esotérico y uno de la Revista Libro Mágico, de diferente año y mes de publicación.

La metodología utilizada para este trabajo parte del paradigma cualitativo, que hace énfasis en casos, objetos o situaciones individuales, por lo que no busca la representatividad, sino lo particular y el análisis a profundidad. En este caso, se parte del paradigma indicial desarrollado por Carlo Ginzburg (2008), quien crea esta propuesta retomando ideas del psicoanálisis, el método de indicios en el que basó Arthur Conan Doyle a su personaje Sherlock Holmes y el estudio de rasgos pictóricos propuesto por Giovanni Morelli.

Este paradigma, tal y como apunta Jiménez “(...) presta más atención a lo micro social, es decir, se explican ideas, actitudes y modelos de cultura mediante un examen intensivo de una persona, un documento o una localidad" (2011, p. 22). Es decir, se va de un elemento micro como indicio, al desarrollo de una tesis que se sostiene a través de la observación a detalle del corpus y la desfragmentación del mismo en diversas categorías de análisis, derivadas de la observación del objeto de estudio: fagotización de santos y símbolos marianos y resemantización de la imagen de la Santa, a través de la feminización, la posmodernidad y la new age.

\begin{tabular}{|l|l|}
\hline \multicolumn{2}{|c|}{ Categorías derivadas de la observación del corpus } \\
\hline Resemantización & $\begin{array}{l}\text { Semantizar se refiere a expresar contenidos y sentidos a través de formas codificadas, es decir, abs- } \\
\text { traer la realidad y significar a través del lenguaje. En este sentido hablar de resemantizantización se } \\
\text { relaciona con el proceso anterior, pero en este caso se toma algo ya semantizado y se inicia el proceso } \\
\text { inverso, para dar “(...) realce a un sentido ya existente, o a uno nuevo recuperado, ya sea en forma total } \\
\text { o parcial” (Zecchetto, 2011, p. 127) }\end{array}$ \\
$\begin{array}{l}\text { Zecchetto (2011) apunta que resemantizar se refiere a una operación semiótica, donde se transforma } \\
\text { el sentido de algo conocido y se renueva, creando una entidad distinta pero relacionada con lo anterior. } \\
\text { La resemantización, según este autor, integra elementos de la analogía, la metáfora y la polisemia. Esto } \\
\text { coincide con ciertas características de los productos posmodernos, donde se retoman elementos del } \\
\text { pasado y se reelaboran en contextos actuales. }\end{array}$ \\
\hline
\end{tabular}




\begin{tabular}{|l|l|}
\hline Fagotización & $\begin{array}{l}\text { Fagocitar se refiere al proceso mediante el cual algunas células u organismos se alimentan de algo a } \\
\text { través de la fagocitosis, es decir, a través de absorber, subsumir o incorporar algo (Real Academia de } \\
\text { la Lengua , 2020) }\end{array}$ \\
& $\begin{array}{l}\text { En este sentido, se transfiere un término de la biología, para explicar el proceso a través del cual la ima- } \\
\text { gen de la Santa Muerte ha absorbido características y prerrogativas propias de otros santos o vírgenes, } \\
\text { es decir, se ha alimentado de ellos para reconstruirse a través de la imagen. }\end{array}$ \\
\hline
\end{tabular}

Fuente: Elaboración propia.

Es importante mencionar que este método cualitativo se acerca a la fuente o corpus de análisis buscando su valor a partir de la interpretación cultural por lo que deja de lado su valor estético, de ahí que en este trabajo no se considere la calidad en la imagen o el diseño analizado.

\section{RESULTADOS}

\subsection{La Santa Muerte en las Revistas Mundo Esotérico y El libro mágico}

El culto a la Santa Muerte, que se difundió a través de los medios, supuestamente tuvo origen en la época prehispánica. Sin embargo, Perdigón (2017) apunta que la representación que pervivió a través los siglos se relaciona más con la religión judeocristiana, que con los antiguos cultos a la muerte que se llevaban a cabo en el México prehispánico. Sin embargo, es cierto que la representación visual de la misma se va complejizando a través del tiempo e integra elementos simbólicos y culturales de diversas épocas y contextos, tal y como se observa en los párrafos siguientes.

Los ejemplares a analizar corresponden a los años 1997, 2000 y 2001. A continuación se describe la portada más antigua, pues es a partir de esta que se observará la resemantización de la imagen de esta Santa. La portada es un número especial de la revista, dedicado a las imágenes milagrosas entre las que se coloca una representación de Kali, la diosa hindú de la venganza, denominada en este ejemplar como la diosa hindú para levantar negocios; en la esquina superior derecha, justo abajo, se observa una imagen de San Martín Caballero, seguida por una San Judas Tadeo; un big close up del rostro de una virgen, del lado izquierdo, inferior; y únicamente se encuentra una representación en medium shot de San Judas Tadeo. Las cuatro figuras son pequeños recuadros con una medida de $4 \mathrm{~cm} \times 3 \mathrm{~cm}$.

La imagen central es una representación de la Santa Muerte de cuerpo entero, esta se encuentra flotando sobre las nubes, las cuales presentan un alto contraste entre luz y sombra, las partes iluminadas tienen un color dorado. La luz del atardecer llega por la espalda de la figura, creando un halo a su alrededor. La representación es una imagen de bulto, probablemente de yeso o cerámica blanca, y se encuentra en el centro de la portada de la publicación, ocupando dos cuartos de la misma (Fig. 5).

Figura 5. Revista Mundo Esotérico número 10

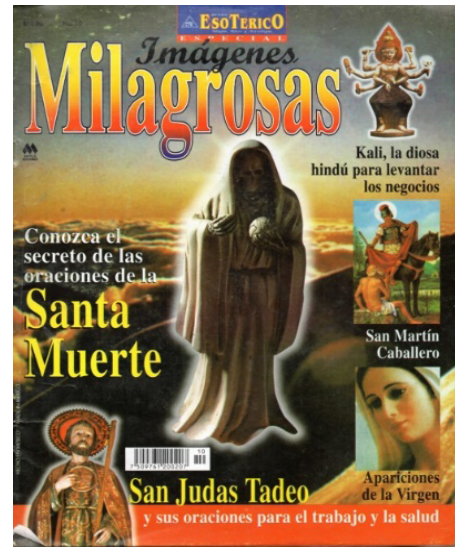

Mina Editores (Octubre, 1997)

La imagen de la muerte que se utilizó en esta portada corresponde a la forma del esqueleto seco. Elsa Malvido (2005) apunta que esta es una de las cinco representaciones más comunes durante la Edad Media, 
donde predominaron las iconografías de danzas macabras cuyo personaje principal era la muerte, segadora de vidas que bailaba entre la multitud tomando la vida de los presentes sin considerar edad, clase social o sexo.

Las imágenes descritas en el párrafo anterior se remontan a la Europa del siglo XIII, época en que la iglesia católica promovió las prácticas de la buena muerte que tuvieron gran aceptación entre la población, debido a los diversos procesos históricos epidemiológicos, tales como la peste. Para la promoción de estas prácticas, los religiosos tuvieron que dar forma a una idea: la muerte, de ahí derivaron estas representaciones (Malvido, 2005).

Estas imágenes medievales llegaron junto con la Inquisición a México e introdujeron una nueva estética de la muerte en el mundo prehispánico, así como el concepto de infierno (Reyes, 2011). En el México prehispánico, los antiguos pobladores rendían culto a la muerte como parte de su comprensión del mundo en una reiteración cíclica de la vida, el renacimiento y la naturaleza (Perdigón, 2017), por ello, aceptaron la representación de la muerte como esqueleto seco como algo familiar, creándose una hibridación del concepto que tal y como apunta Reyes, “(...) generó nuevos ritos y costumbres que fueron enriqueciéndose con el tiempo" (2011, p. 52) .

La imagen que se observa en 1997 en la portada de la revista Mundo Esotérico, corresponde, tal y como se mencionó, a una reiteración de la imagen medieval que se modificó durante el Renacimiento en los siglo XVI y XVII, donde se incorporaron elementos y símbolos procedentes de la mitología de la Grecia Antigua, como la balanza, el globo terráqueo, la guadaña y el reloj de arena (Flores, 2008). Sin embargo, en esta portada sólo pervive la representación del mundo, el cual la Santa Muerte lleva en la mano izquierda, en otras portadas, tal y como se verá más adelante, se incluyen la guadaña y el rosario.

La imagen que presenta la revista Mundo Esotérico corresponde a la iconografía medieval de los triunfos de la muerte donde aparecía la muerte en su representación de esqueleto seco, no obstante, se aleja del sentido de estas y de la promoción de la buena muerte, cambiando la idea de la segadora de vidas a la protectora de vidas (Fig. 6).

Figura 6. Imágenes de la Santa Muerte medieval

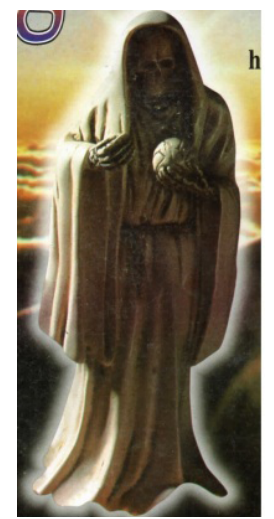

Santa Muerte. (Mina Editores, 1997)

\footnotetext{
4 De este modo, el culto a la muerte en México permaneció en el tiempo pero de manera marginal, ya que como apunta Malvido (2005) a partir de 1775 , las autoridades eclesiásticas prohibieron venerar cualquier representación de la muerte. Así, si bien se utilizaron imágenes de esta para evangelizar, en las festividades y danzas que hacían alegoría a la misma, la figura cada vez más predominante era la misma Muerte, dejando a un lado a Dios, por lo que estos rituales fueron considerados idolatría. Perdigón (Reyes-Ruiz, 2011) rastreó la historia y desarrollo de este culto, la autora registra la existencia de una figura esquelética, llamada San Pascual Bailón, que era venerada en Chiapas y Guatemala durante el siglo XVII. Una figura similar apareció durante el siglo XVIII, específicamente en 1793, en el pueblo de Amoles, Querétaro, la imagen, de nombre Justo Juez, era un esqueleto de cuerpo entero, que portaba arco y flecha. Para 1797, en Guanajuato se realizaba una ceremonia donde se amarraba y azotaba a la representación de un esqueleto llamado Santa Muerte, con la finalidad de que les cumpliera el milagro. Durante el siglo XIX, las representaciones religiosas de la Muerte disminuyeron, siendo recuperadas a final de siglo por el grabador José Guadalupe Posada, quien rescató la iconografía medieval y las representaciones de la danza macabra. Es casi sesenta años después que se vuelven a encontrar menciones a esta figura en el trabajo "Los Hijos de Sánchez", del antropólogo Oscar Lewis. Lewis recupera el testimonio de una de las integrantes de la familia Sánchez, donde se menciona a San Crispín o la Santa Muerte como protector contra las infidelidades. Durante esta década, también se registra su presencia en los estados de Hidalgo y Zacatecas (Reyes, 2011).
} 


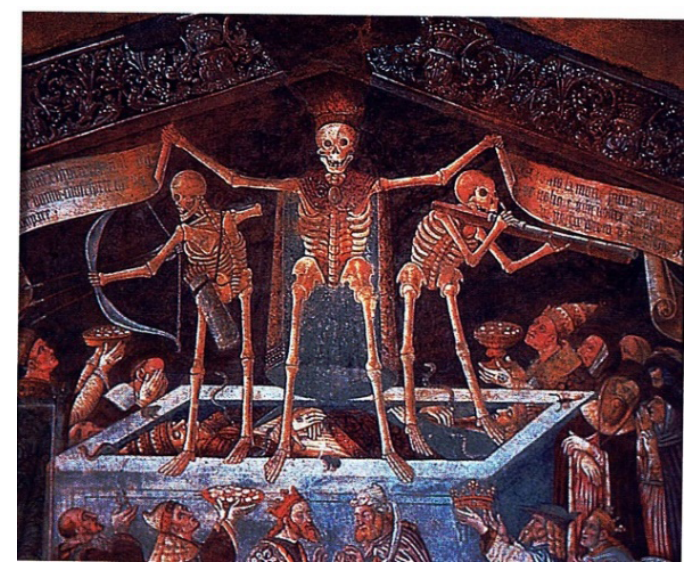

Danza macabra (Malvido, 2005)

\subsection{El proceso de fagocitación de imágenes benevolentes en la imagen de la Santa Muerte}

Si bien la imagen conserva símbolos griegos también son notorios elementos de la iconografía cristiana, como lo es el nimbo o halo, el cual se refiere a la luz que rodea la figura de un santo o virgen católica. El halo, reflejo de la gloria celeste, representa la santidad y la realeza (Blavatsky, 2012), este elemento no pertenece a la iconografía medieval, sino que es un agregado a la reconstrucción connotativa de la figura de la muerte que se fue desarrollando a través de los siglos. Tal y como apunta Lara (2008) en las representaciones de la Santa Muerte perviven diversas visiones epistemológicas: la católica, que implica la representación de la mortalidad humana, donde no se adoraba o encomendaba a la muerte, sino que se buscaba "una buena muerte"; y la resemantización de esta imagen, donde se convierte en una figura de protección, se le invoca, y se confía y acude a ella en caso de problemas (Fig. 7).

Figura 7. Portada. Elementos de la iconografía católica

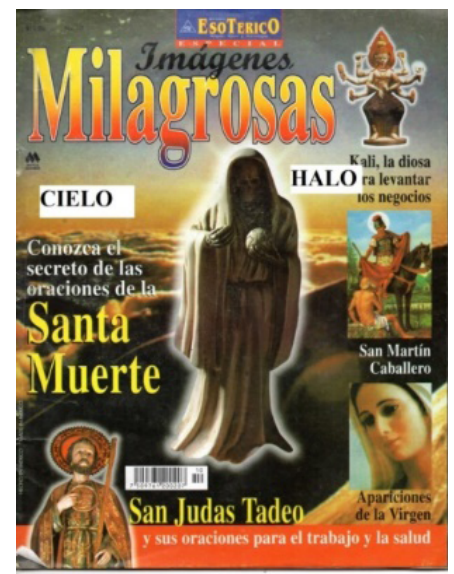

Imágenes milagrosas, (Mina Editores, 1997)

Como ya se mencionó, esta resemantización se visibiliza en la imagen a través del uso del halo, la colocación de la Santa en el cielo iluminado, similar a las imágenes de cristo y las vírgenes (Fig.8), y el traspaso por contagio de características benéficas de los santos y dioses que acompañan la imagen, cuyas características individuales se desglosan a continuación y cuya fagocitación se observa en las imágenes de las revistas de 2000 y 2001. 
Figura 8. Imágenes de la Virgen María

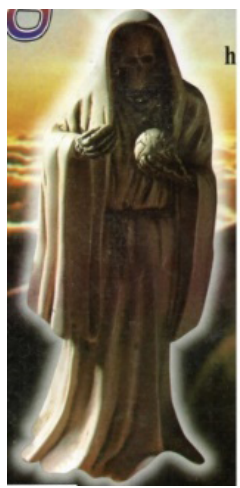

Santa Muerte. (Mina editores, 1997)

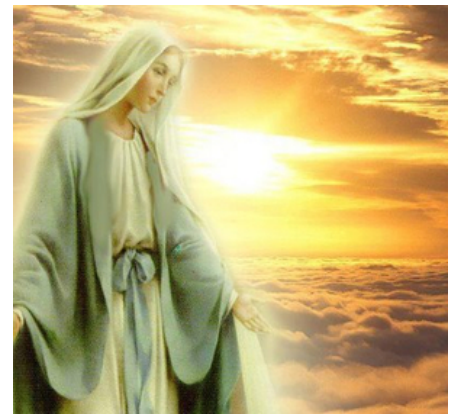

Imagen de la Virgen María (Reina del Cielo, 2013)

En este caso, San Judas Tadeo, discípulo de Cristo, quien murió asesinado mientras predicaba en el año setenta después de Cristo, es considerado mártir y se convitió en el santo de las causas imposibles (Bastpus, 1861). Curiosamente, San Judas no sólo comparte la portada de 1997 con la Santa Muerte (Fig.9), sino también las habilidades como Santa en causas imposibles5. Tal y como apunta Katia Perdigón citada por Lara Mireles "Es la santa de los ladrones y de los asesinos, cierto, pero también de muchísima gente común que le pide el milagro de hallar un empleo. La Santa de aquellos que se cansaron de rogarle a San Judas Tadeo" (2008, p. 294).

Figura 9. San Judas Tadeo

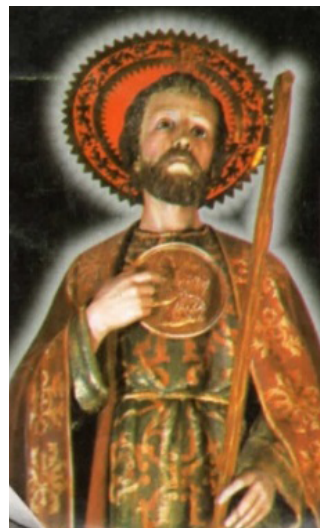

Fragmento de portada, Imágenes milagrosas, (Mina Editores, 1997)

5 Tal es el testimonio de Yolanda, una mujer que fue diagnosticada con un tumor en el intestino y que, según su testimonio, fue sanada por la Santísima: “Ahora con un poco más de conocimiento sobre lo que sucedió se explaya con todos aquellos creyentes, porque efectivamente para la Señora no hay imposibles sobre la tierra ya que lo único que podría serlo es ella misma" (Libro Mágico, 2001, p. 35). 
En esta portada, acompañando a la imagen de la Santa, se osberva a la Virgen de Medjurgorje (Fig. 10). Aquella es un advocación de la Virgen María, cuya serie de apariciones se registraron en Boznia-Herzegovina y correspondió a la imagen de la maternidad, la protección y la paz (virgendemedjugorje, 1982), elementos con los cuales también se le asocia a la Santa Muerte, en la revista Mundo Esotérico ${ }^{6}$ (Figura 10) y con cuya represenctación coincidirá en imágenes mediáticas más actuales de la Santísima, donde emula a una virgen de manto blanco:

Estos procesos afloran a través de las pinturas y creaciones artísticas y diseñadores gráficos, que de algún modo hibridan plásticamente las prácticas devocionales y experiencias de amplias capas de la población de origen mexicano (...) Artistas y diseñadores gráficos han ensamblado símbolos, formas y rasgos de ambas entidades, hasta crear un producto híbrido (Flores, 2008, pp. 67-68)

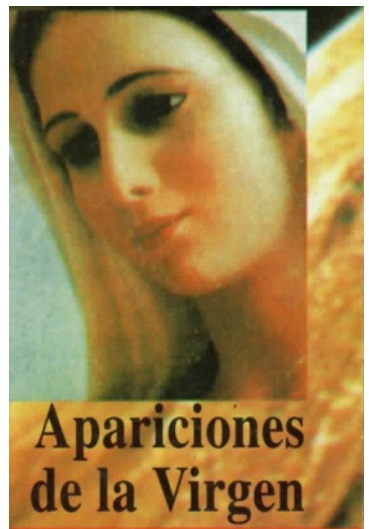

Fragmento de portada, Imágenes milagrosas, (Mina Editores, 1997)
Figura 10. Vírgenes y Santa Muerte
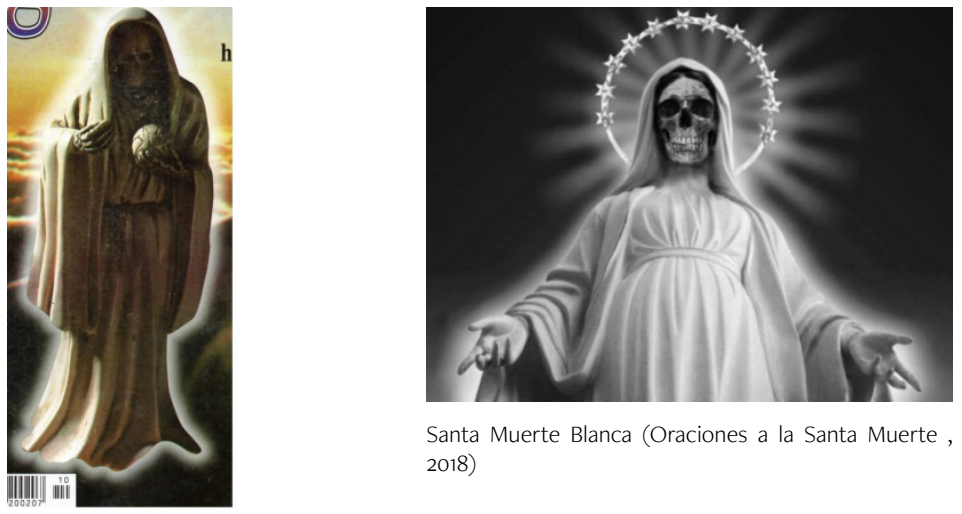

Santa Muerte Blanca (Oraciones a la Santa Muerte, 2018)

Santa Muerte. (Mina Editores, 1997)

De igual manera, encontramos a San Martín Caballero (Fig. 11), cuya leyenda relata un acto de generosidad realizado por el entonces soldado romano, quien compartió su manto con Jesús, que se le presentó como un pobre que tiritaba de frío y se le reveló en un sueño como hijo de Dios, razón por la cual el soldado decidió dejar las armas, bautizarse y seguir una vida ejemplar (catholic.net, 2019). Al igual que con los otros personajes que le acompañan en la portada, la Santa también puede asumir las peticiones hechas a San Martín para lograr la abundancia y proteger los negocios?.

Figura 4. San Martín Caballero y La Santa Muerte

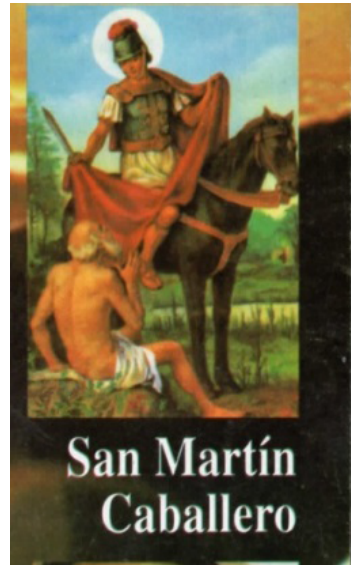

La Santa Muerte dorada supuestamente se encarga de proteger los negocios y la economía (Hablemos de religión, 2019)

Fragmento de portada, Imágenes milagro-

sas, (Mina Editores,1997)

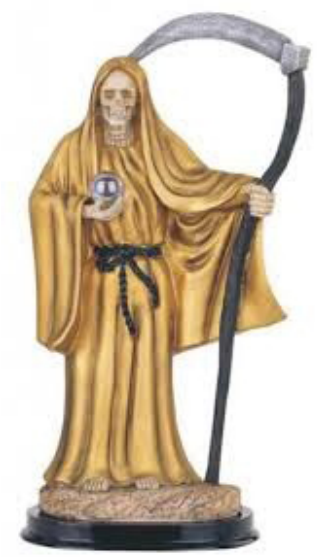

6 Señora Nuestra permítenos acogernos en tu manto redentor, a tu balanza de justicia y tu poderosísimo amor por los que te nombramos (Libro Mágico, 2001, p.15).

$7 \quad$ Así lo muestra el testimonio de Guadalupe García, quien señala “Entonces le pidió a la Santísima que le concediera un negocio, aunque fuera pequeñito para no andar con tantas carencias (...) “Y la señora me escuchó" (Mina Editores, 2001) 
Los tres elementos anteriores vinculan a la Santa Muerte con la bondad, la beatitud, y la protección, presentándose únicamente una imagen ambivalente que conserva rasgos de cierta oscuridad, en este caso, la diosa Kali, perteneciente a la mitología hindú que es uno de los desdoblamientos de la diosa Parvati, esposa de Shiva, quien representa el ciclo natural de muerte y destrucción, es la diosa más temible y violenta. Representa también la protección, la ruptura con el ego y consecución de deseos (Cartwright, 2013). Es de alguna forma una representación no occidental de la muerte, que antecede a la imagen central de esta revista.

La Santísima absorbe las prerrogativas que atienden los santos y dioses que le acompañaban en esta portada: cubre las necesidades de protección, amor, cumple deseos, protege los negocios, etc., con un plus, la Santa carece de la mirada escrupulosa de los santos, su relación con el devoto depende de que este cumpla lo prometido, y ella cumplirá lo solicitado. Tal y como apunta Flores (2008), uno de los principales rasgos del culto a la Santa Muerte es el individualismo, puesto que implica una serie de rituales magico-religiosos focalizados en el individuo, donde este reconfigura oraciones, rituales, altares, ofrendas y adapta sus experiencias prácticas y lo aprendido en los medios al culto de "su santa". De este modo, tal y como señala De la Torre (2012), la New Age y la nueva sensibilidad no solo concuerdan con la religiosidad popular sino que se entremezclan, coincidiendo en un hibridismo posmoderno, en una sociedad donde los medios tienen un papel preponderante ${ }^{8}$.

Lo anterior explicaría la construcción visual de la portada que se analiza donde confluyen elementos católicos con elementos paganos, conformando un culto popular que se entremezcla con lo que Hanegraff (1999) denomina una nueva religiosidad.

Esto se relaciona de manera directa con otra de las características ya mencionadas de la posmodernidad que es el “(...) debilitamiento de la historicidad, tanto en nuestra relación con la historia pública, como en las nuevas formas de nuestra temporalidad privada, cuya estructura "esquizofrénica” (...) determinará nuevos tipos de relaciones sintácticas o sintagmáticas" (Jameson, 1991, p.4), donde la devoción a la Santa Muerte y la fagocitación de otros santos y cultos se asume como normal y no es cuestionada por los devotos (Fig. 12). Los devotos han conformado un culto propio, lleno de simbolismo, prácticas y ceremonias que se alimentan de los medios y la mezclas inter-religiosas, como se observa en la siguiente imagen, publicada en El libro Mágico tres años después de la portada analizada. En esta imagen se encuentra a San José cargando al niño Jesús (1), San Jesús Malverde (2), una rana de la prosperidad (3), un troll (4), Buda (5), una vela levanta negocio (6), los cuatro profetas(7): Isaías, Jeremías, Ezequiel y Daniel; San Martín Caballero (8), Ángeles (9) y la Santa Muerte (10).

Figura 12. Inter-religiosidad en la revista Mundo Esotérico

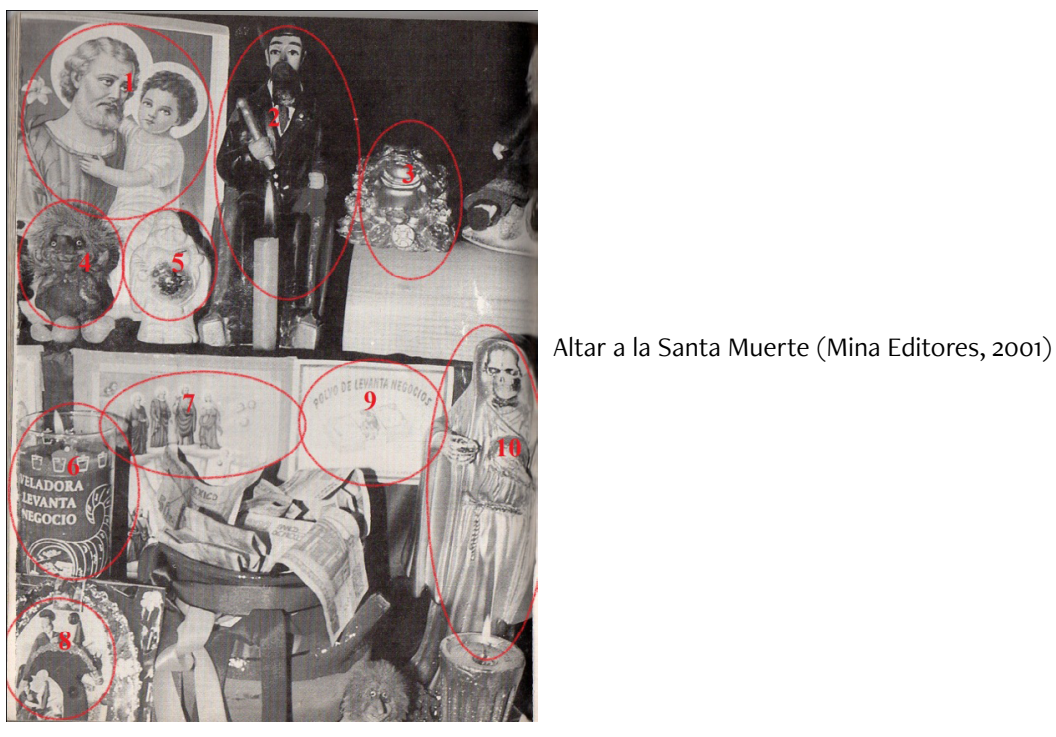

8 Cabe mencionar que la imagen de la revista en 1997, precedió al primer altar en la vía pública, el cual fue expuesto en la calle Alfarería número 12, en la colonia Morelos, en 2001 (Reyes, 2011), mientras que la portada se publicó cuatro años. 
Otro aspecto que cabe resaltar en esta portada de 1997 es que, pese a que en el texto se le denomina Santa Muerte, la imagen que se observa es una representación masculinizada de la misma, pues viste el sayal de los monjes franciscanos, que se aleja de la representación asexual de la muerte que encontramos en las danzas macabras medievales. En este caso, la imagen de 1997 coincide más con figuras como el "El Justo Juez", "San Crispín”, "San Bernardo”, “San Pascual Bailón” y “San Pascualito Rey”.

Por el contrario, la imagen que se encuentra en la revista Mundo esotérico en el año 2000 (Fig. 13) refleja una tendencia a la feminización, donde la muerte se convierte visualmente en Santa, con poderes similares a los de las vírgenes que son intermediarias ante Dios, obviando las características de virginidad y beatitud, puesto que la Santa no discrimina entre peticiones bondadosas o negativas. De ahí que su culto se visibilice con mayor fuerza “(...) en grupos implicados en la marginación, la delincuencia, la pobreza y la inseguridad urbanas, y que explican su expansión asociada a espacios sociales urbanos en donde la pobreza y marginación se encuentran en fuerte incremento" (Campos citado por Flores, 2008, p. 59).

Figura 13. Imágenes de la Santa Muerte en la revista Mundo Esotérico número 119

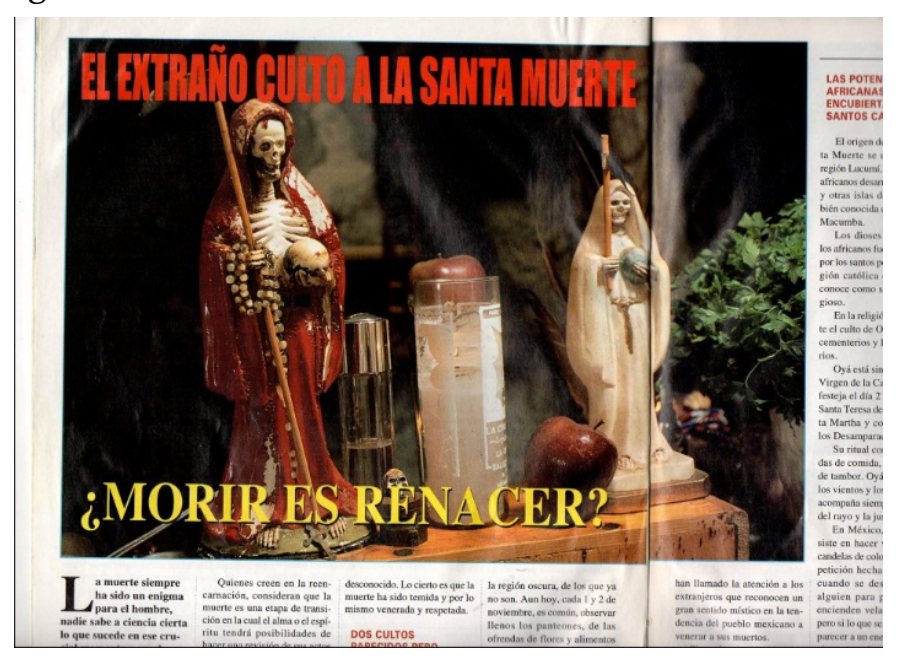

Extraño culto a la Santa Muerte (Mina Editores, 2000, p. 18)

En las imágenes de la revista El Libro Mágico, núm. 12 y Mundo Esotérico núm. 135, de agosto del 2001 y junio del mismo año respectivamente, la Santa Muerte ya porta el hábito de las monjas y el rosario (Fig. 14 y Fig. 15), que es uno de los símbolos marianos de mayor importancia en la fe católica:

Según el Papa Pío V (1569) <<El Rosario o salterio de la Virgen, es un modo piadosísimo de oración, al alcance de todos, que consiste en ir repitiendo el saludo que el ángel le dio a María; interponiendo un Padrenuestro entre cada diez Avemarías y tratando de ir meditando mientras tanto en la Vida de Nuestro Señor>>. El Rosario constaba de 15 Padrenuestros y 150 Avemarías, en recuerdo de los 150 Salmos. Ahora son 20 Padrenuestros y 200 Avemarías, al incluir los misterios de la luz (Sgarbossa, 2018). 
Figura 14. Santa Muerte con hábito de monja

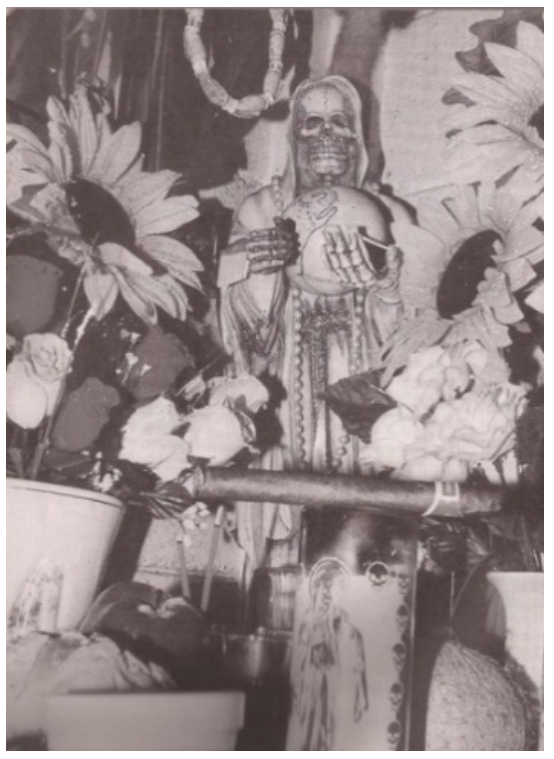

Altar de la Santa Muerte (Mundo Esotérico. Número especial, 2001, p.62)
Figura. 15 Santa Muerte con rosario y mundo

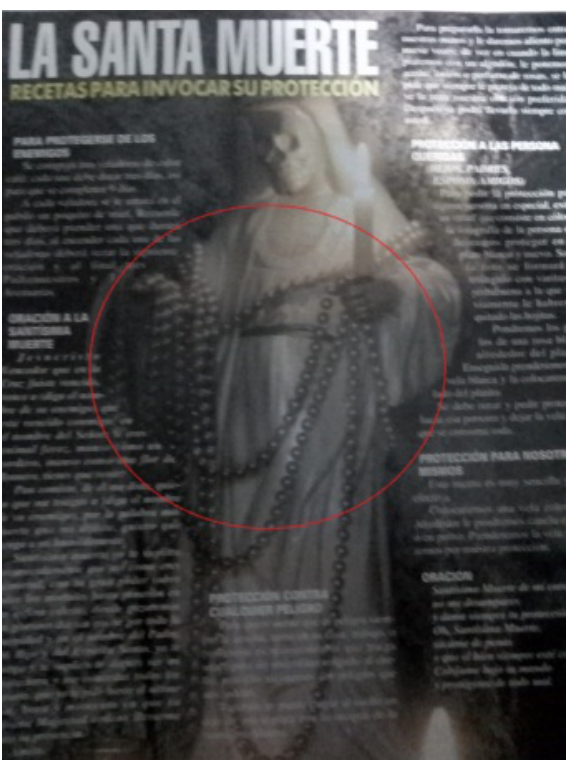

Santa Muerte Blanca (Mina Editores, 2001, p. 28)

Esto lleva a identificar una traspolación de símbolos marianos, que deriva de la fagocitación de los cultos antes mencionados. A través de la feminización de la imagen de la Santa, se abre paso la reasignación de otra característica vinculada con la Virgen María. No sólo se retoman símbolos como el rosario o la vestimenta, sino que se le maternaliza. Tal y como apunta Largarde, la virgen simboliza a la madre esposa que es uno de los cautiverios que esta autora identifica como una manera de ser y vivir de las mujeres, ser madre esposa,

...consiste para las mujeres en vivir de acuerdo con las normas que expresan su ser -para y deotros, realizar actividades de reproducción y tener relaciones de servidumbre voluntaria, tanto con el deber encarnado en los otros, como con el poder en sus más variadas manifestaciones (2014, p. 363).

En este caso la Santa se convierte en madre-virgen- protectora de sus hijos-devotos. La resignificación de la muerte como virgen se observa con mayor claridad en imágenes más actuales del culto donde, en representaciones tradicionales de la maternidad y de la Virgen María, se intercambia la imagen de esta última por la de la Santa. Tal es el caso de La Piedad, de Miguel Ángel, la cual es reinterpretada en este culto popular (Fig. 16 y Fig. 17).

Figura 16. Santa Muerte Piadosa

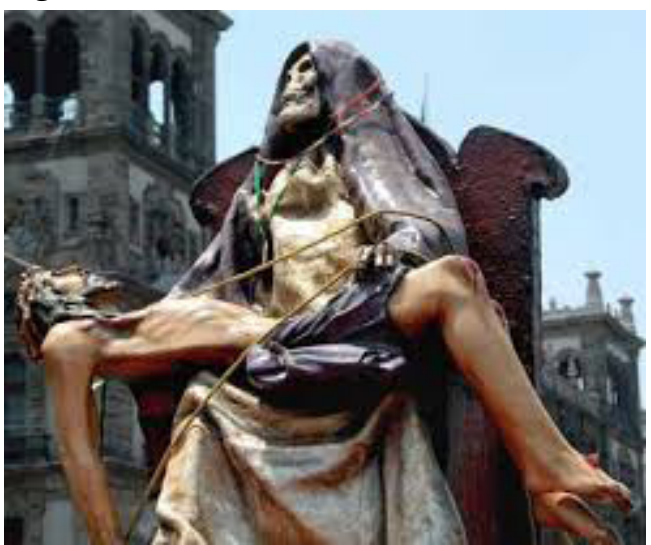

Imagen de la Santa Muerte Piadosa (Imágenes de la Santa Muerte, 2019)
Figura 17. La Piedad

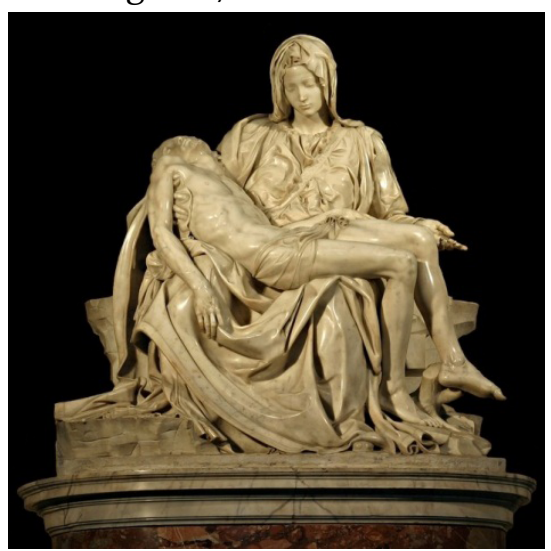

La Piedad, de Miguel Ángel (González, 2019) 
Las imágenes que se encuentran en la revista Mundo Esotérico responden a dos explicaciones distintas. En 1997 se utiliza la imagen de la Santa, que corresponde a las danzas macabras y a la buena muerte medieval. La explicación que se presenta es la historia veracruzana, que cuenta que la muerte se le apareció a un brujo, dejando su imagen impresa en una de las paredes.

Conforme avanza el posicionamiento del culto y, por supuesto, su representación visual, la explicación se va complejizando y se empieza a trazar una línea que ubica, de acuerdo con esta revista, las raíces del culto a la muerte en la época prehispánica y recupera imágenes de esculturas de dioses prehispánicos, cuya representación incluía cráneos o huesos. De esta manera, se legitima en la imagen (Fig, 18) la procedencia de un culto que, como se ha visto, tiene más de la reconfiguración actual del mexicano en un contexto incierto, donde la religión católica y cristiana colapsan, que de las raíces prehispánicas y del culto a los muertos en la antigüedad.

Las imágenes se colocaron de manera descontextualizada, es decir, no se indica la fecha, nombre o periodo en que fue realizada la escultura ni su significado, únicamente se apela a que son de origen prehispánico y se usan para justificar el supuesto origen "antiguo" del culto a la Santa Muerte (Fig. 18 y Fig. 19).

Figura 18. Escultura de Tlatilco

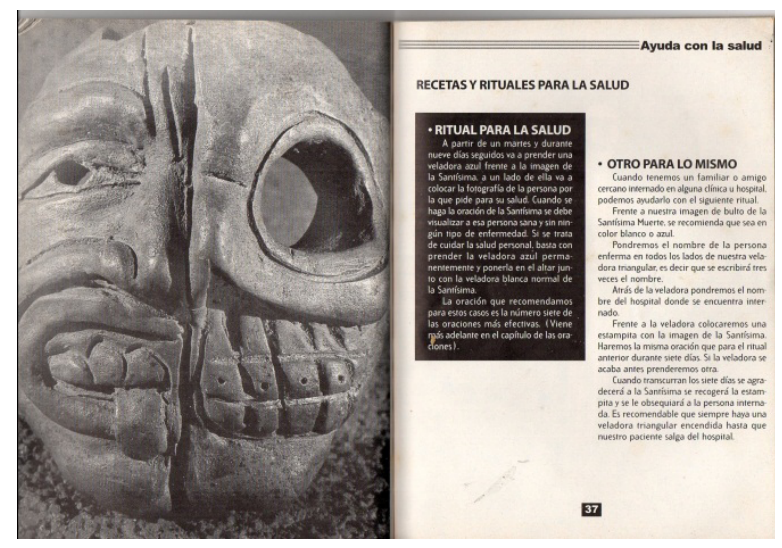

Máscara dual, La vida y la muerte. Tlatilco. Preclásico Medio. Recetas y rituales (Mina Editores, 2001, p. 37)

Figura 19. Escultura de Mictlantecuhtli

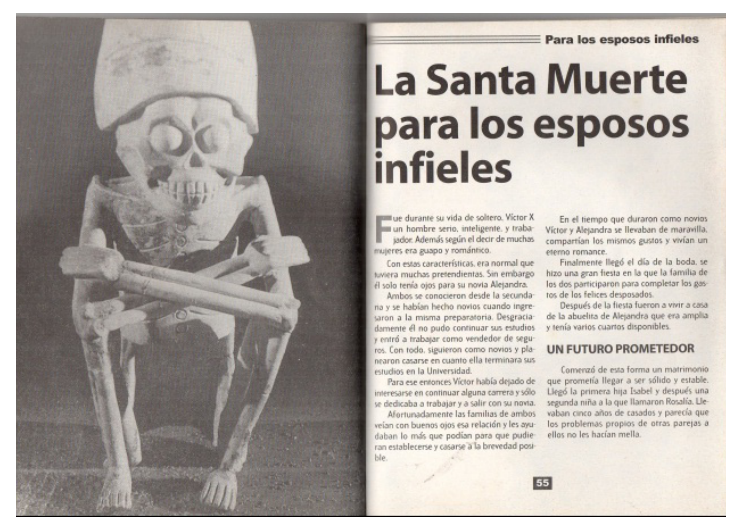

Mictlantecuhtli, señor de a muerte. Santa Muerte para los infieles (Mina Editores, 2001, p.55)

Ahora bien, es cierto que estas representaciones visuales en torno al culto de la Santa Muerte integran elementos culturales de diversas religiones. Esta hibridación se ha dado conforme el culto a esta Santa crece y se legitima. Además, se refleja en las representaciones de la misma, que se complejizan y van integrando más y más elementos, como por ejemplo, el uso de colores en las imágenes que se relacionan con las peticiones que se le hacen a la Santa (Fig. 20): rojo para el amor, verde para la salud, amarillo o dorado para el dinero, negro para la magia negra, etc. "Los colores rojo, negro, blanco, amarillo con que viste, refieren 
las necesidades y deseos y probablemente quieren expresar que el paso exitoso por la vida precisa de la realización de los mismos" (Castells-Ballarin, 2008, p. 15).

Figura 20. Portada Libro Mágico, núm. 12

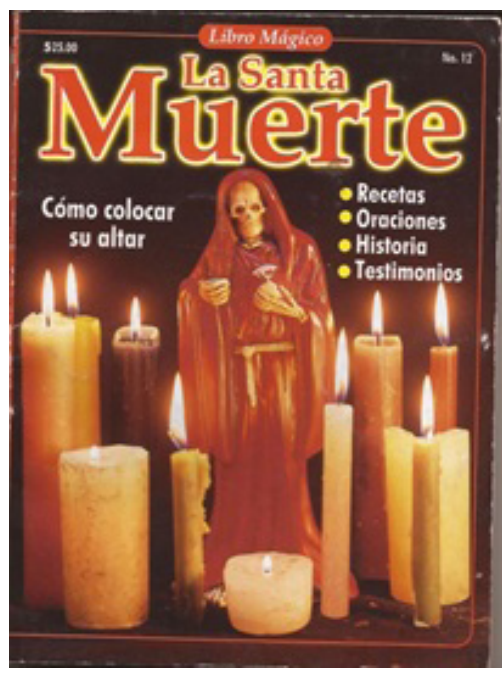

Portada (Mina editores, 2001)

Esta resemantización también se observa en las revistas de 2001, en específico en la publicación de El libro Mágico (Mina Editores, 2001), donde la Santa toma el lugar central de la portada y ya no comparte espacio con ningún otro santo, es decir, la fagocitación ya es completa. La imagen que se presenta es una representación del esqueleto seco que viste un sayal rojo y se encuentra en el centro de una serie de velas de diversos tamaños y grosores. La revista es un número especial, dedicado por completo a la Santa Muerte y es una legitimación simbólica de esta como Santa: la portada anuncia que dentro se detalla cómo colocar el altar, oraciones, recetas, testimonios e incluso la historia del culto.

Tal y como se mencionó en párrafos anteriores, esta búsqueda de legitimación se encuentra de manera visual en toda la revista. Como apunta Flores "deforman los perfiles, se manipulan los contenidos y la ideología y el nacionalismo toman la palabra, para reinvidicar lo "antiguo" del culto, solapando el carácter absolutamente moderno y contemporáneo del mismo" (2008, p.58).

Sin embargo, en este caso, se observa un culto más posmoderno que moderno, que busca una legitimación no sólo mediática, sino también en el imaginario colectivo, que en medio del caos intenta asirse al pasado prehispánico y al culto colonial mariano, impuesto a los antiguos pobladores de este país, en busca de un sentido a la vida y a la muerte, en un contexto donde la inseguridad y la muerte es el pan de cada día. Como señala Gaytán "En este mundo es necesario proteger la vida rindiendo culto a la muerte para implorar su protección, para que al menos la vida no sea tan sufrida y la agonía no carcoma el sentido de vivir" (2008, p. 41).

Aunado a lo anterior, se encuentra el reciente uso de la imagen de Yemaya, una diosa cubana, que se ha convertido en una de las más recientes advocaciones de la Santa Muerte y que en los puertos de Veracruz se conoce como la joven muerte encarnada (Flores, 2008). La imagen siguiente no pertenece a las revistas analizadas, ya que es mucho más actual. Sin embargo, es importante observar que en esta versión de la Santa Muerte, el proceso de feminización se ha completado y no sólo se tendió a la maternalización, sino a la erotización de la representación, determinada por la exaltación del cuerpo femenino, donde la carne, cubre los huesos de la muerte (Fig. 20). 
Figura 20. Santa Muerte Encarnada

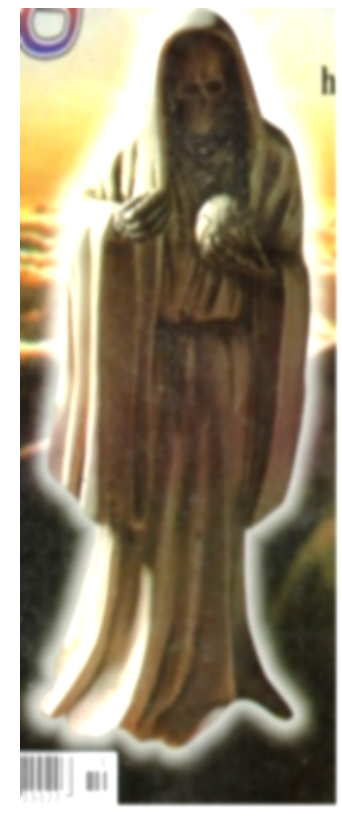

Santa Muerte. (Mina Editores, 1997)

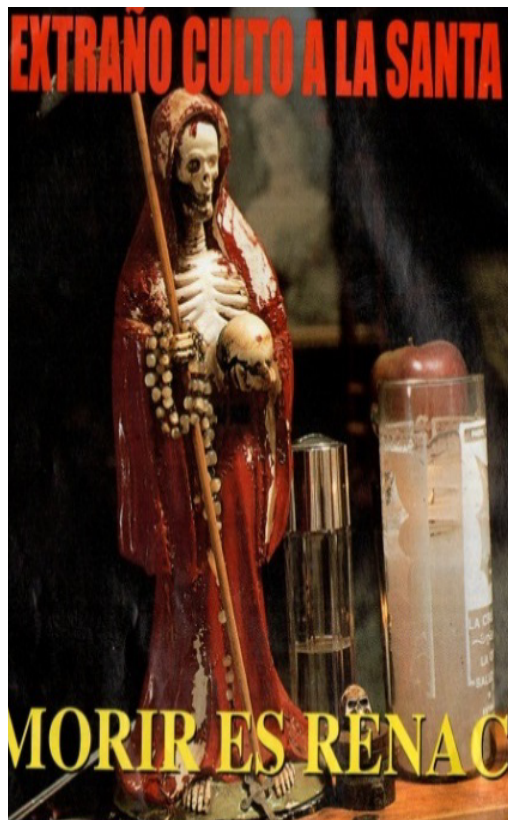

Extraño culto a la Santa Muerte (Mina Editores, 2000, p. 18)

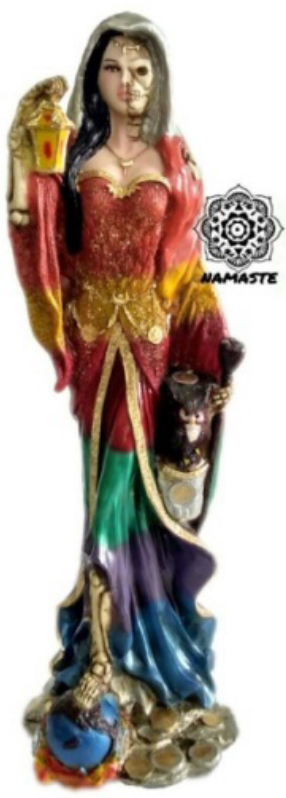

Santa Muerte Encarnada (Mercado libre, 2018)

\section{CONCLUSIONES}

En conclusión se observa que las rupturas de la posmodernidad que se originaron en la década de los 50 del siglo pasado, abrieron posibilidades para el surgimiento o la visibilización de prácticas religiosas y cultos populares que habían permanecido marginales. Esta visibilización se dio de la mano con la conformación de nuevas religiosidades, entre las que predominó la New Age, movimiento religioso que según Hanegraff (1999) implica una nueva religiosidad, en la que confluyen elementos de la natural filosofía, el neopaganismo, el milenarismo y las temáticas centradas en la salud y el crecimiento personal. Estos elementos se van a visibilizar y reiterar a través de los medios masivos de comunicación, cuyo papel será fundamental dentro de esta nueva religiosidad y dentro de la misma posmodernidad, ya que como apunta Jameson (1991), las características de esta se darán dentro de una época específica, la era de los medios de comunicación marcada por:

1. Una nueva superficialidad

2. El consiguiente debilitamiento de la historicidad

3. Todo un nuevo subsuelo emocional

Esta nueva superficialidad coincide con el movimiento de la New Age, que se caracteriza por una mezcla religiosa, cuyos productos integran elementos del paganismo, la cristiandad, el sintoísmo, lo prehispánico, etc., sin preocuparse por la coherencia ontológica de los mismos. Ni el medio que lo promueve ni quien lo consume, se pregunta por los orígenes de los cultos que se interrelacionan entre sí ni de los rituales que corresponden a cada religión. De ahí que el culto a la Santa Muerte parezca prehispánico, medieval y católico, sin ser ninguna de las tres cosas.

Es en este contexto que un culto que había permanecido en la marginalidad se va legitimando y reconfigurando en un confluir entre los devotos y los medios y viceversa, el culto a la Santa Muerte. La legitimación y resemantización que observamos en las revistas Mundo Esotérico y Libro Mágico, cuyas imágenes de la Santa Muerte, que van de 1997 a 2001, se van modificando conforme el culto a la Santa crecía y recibía 
mayor cobertura por parte de los medios.

Las imágenes de la Santa muestran la fagocitación de cultos alternos y prácticas populares. De este modo, en las primeras imágenes que analizamos se observa la representación de la muerte a través de la imagen medieval, pero desvinculada de la buena muerte y las danzas macabras, que dieron origen a la representación de esqueleto seco con el sayal franciscano y que poco a poco se fue modificando hasta adquirir características similares a las de las vírgenes y santos. Esas transformaciones incluyeron en su representación el halo, el rosario, el cambio del sayal franciscano por el hábito de las monjas, mostrando un proceso de resemantización de la imagen, tendiente a la maternalización de la misma, en un símil con la virgen María, a quien se le asignan las características del cautiverio de madre-esposa.

El proceso de resemantización de la imagen de la Santa Muerte va de la mano con las necesidades de los devotos ya que, tal y como lo menciona Flores (2008), el culto a la Santa Muerte es un culto individual, de modo que el creyente incorpora los elementos que considera para la representación y adoración de la misma. De ahí la inclusión de flores, ofrendas y otros elementos como las bebidas alcohólicas, cigarros y panes, así como festejos con música y banquetes.

De igual modo va derivando en la modificación gradual de la imagen, ajustando esta a un imaginario colectivo donde permean los signos católicos y medievales, así como las construcciones de género. Dichos elementos, se trasminan poco a poco en las representaciones mediáticas y culturales de este culto posmoderno. Este proceso de feminización de la imagen de la santa no deriva únicamente de las rupturas de la posmodernidad, que permite la migración de elementos del pasado y de origen diverso para reconfigurarse en el presente, sino de un proceso histórico, donde se percibe una tendencia gradual hacia la feminización de la religión, tal y como señala Welter citada por Mínguez "En el periodo inmediatamente posterior a la Revolución americana (...) la religión experimentó un proceso de cambio a través del cual se hizo más domesticada, más emocional, más indulgente y condescendiente, en una palabra, más $<<f e m e n i-$ na>>" (2015, p. 401). Dicho proceso no se vivió solo en Estados Unidos, sino en toda América, y en México dio frutos debido al fuerte arraigo al culto de la virgen de Guadalupe.

\section{REFERENCIAS}

Argyriadis, K. (2014). Católicos, apostólicos y no satánicos: Representaciones contemporáneas en México y construcciones locales (Veracruz) del culto a la Santa Muerte. Cultura y religión, 8(1), 191-218. https://www.revistaculturayreligion.cl/index.php/culturayreligion/article/view/451

Bastpus, J. (1861). Nomenclator sagrado. Librería Subirán.

Becerril, A., \& Muñoz, A. E. (2005, Abril). Cancelan el registro de asociación religiosa a la Iglesia Mex-USA. La Jornada. Recuperado de: https://cutt.ly/XhKik7a

Blavatsky, H. P. (2012, Septiembre). Glosario de teosofía. Recuperado de: https://glosarios.servidor-alicante.com/teosofia

Cartwright, M. (2013, Junio) Ancient history enciclopedia. Recuperado de: https://www.ancient.eu/Kali/

Castells-Ballarin, P. (2008). La Santa Muerte y la cultura de los derechos humanos. Revista LiminaR. Estudios sociales y humanísticos, VI (1) 13-25. https://doi.org/10.29043/liminar.v6i1.263

De la Torre, R. (2012). La religiosidad popular como "entre-medio" entre la religión institucional y la espiritualidad individualizada. Civitas, 12 (3), 506-521. https://doi.org/10.15448/1984-7289.2012.3.13013

Flores, J. A. (2008). Transformismos y transculturación de un culto novomestizo emergente: La Santa Muerte Mexicana. En M. Cornejo, M. Cantón, y R. Llera (Coord.), Teorías y prácticas emergentes en antropología de la religión, (pp. 55-76). Ankulegi Antropologia Elkartea.

Fragoso, P. (2011). De la "calavera domada" a la subversión santificada. La Santa Muerte, un nuevo imaginario en México. El cotidiano, (169) 5-16. https://biblat.unam.mx/hevila/ElCotidiano/2011/no169/1.pdf

Gaytán, A. F. (2008). Santa entre los malditos. Culto a la Santa Muerte en el México del siglo XXI. Liminar. Estudios sociales y humanísticos, 4(1), 40-51. https://doi.org/10.29043/liminar.v6i1.265

Ginzburg, C. (2008) Mitos, emblemas, indicios. Morfología e historia. Gedisa.

González, J. (s.f.). Miguel Ángel Buonarroti, La Piedad del Vaticano. Mármol, 1499. Departamento de Educación, Universidad Francisco Marroquín. https://cutt.ly/ShKiRif 
Hablemos de religión. (2019). Santa muerte dorada: Historia, significado, oración y más. Recuperado de: https://hablemosdereligion.com/santa-muerte-dorada/

Huffschmid, A. (2012). Devoción satanizada: La Muerte como nuevo culto callejero en la Ciudad de México. iMex. México Interdisciplinario, (3) 97-107. https://cutt.ly/vhKiPQZ

Hanegraaff, W. (1999). New Age Spiritualities as Secular Religion: a Historian's Perspective. Social Compass, 46(2),14516o. https://doi.org/10.1177\%2Fo03776899046002004

Imágenes de la Santa Muerte. (2019). Imágenes de la Santa Muerte. Recuperado de: http://imagenesdelasantamuerte.com/imagenes-de-la-santa-muerte-la-piadosa/

Jameson, F. (1991). La lógica cultural del capitalismo tardío. Centro de Asesoría y Estudios Sociales.

Jiménez, A. (2011). Carlo Ginzburg: reflexiones sobre el método indiciario. Esfera, 1(1), 21-28. https://revistas.udistrital. edu.co/index.php/esfera/article/view/5789

Kristensen, R. (2019). Mudarse y mudarse: sobre el intercambio y la familia en el culto a la Santa Muerte. En W. G. Pansters (Coord.), La Santa Muerte en México: historia, devoción y sociedad, (pp. 136-157). University of New Mexico Press. https://muse.jhu.edu/book/66917

Kristensen, R. A. (2014). How did Death become a Saint. Ethnos: Journal of Anthropology, (81) 1-23. https://doi.org/10.1 080/00141844.2014.938093

Kristensen, R. A. (2015). La Santa Muerte in Mexico City: The Cult and its Ambiguities. Journal of Latin American Studies, 47(3) 1-24. https://doi.org/10.1017/So022216X15000024

Lagarde, M. (2014). Los cautiverios de las mujeres. Madresposas, monjas, putas, presas y locas. UNAM-Siglo XXI.

Lara Mireles, M. C. (2008). El culto a la Santa Muerte en el entramado simbólico de la sociedad del riesgo. Anuario Coneicc, (XV) 285-298. https://doi.org/10.38056/2008aiccXV316

Malvido, E. (2005). Crónicas de la Buena Muerte a la Santa Muerte. Arqueología Mexicana, 76, 20-27.

Mercado libre. (2018). Santa Muerte. Recuperado de: https://cutt.ly/ohKiNj4

Mínguez, R. (2015) ¿Dios cambió de sexo? El debate internacional sobre la feminización de la religión y algunas reflexiones para la España decimonónica. Historia Contemporánea, 51, 397-426. https://doi.org/10.1387/hc.14714

Mina Editores. (1997). La Santa Muerte. Mundo esotérico. Magia, ritos y astrología, 10

Mina Editores. (2000). El extraño culto a la Santa Muerte. Mundo esotérico. Magia, ritos y astrología, 120, 18.

Mina Editores. (2001). La Santa Muerte. Libro mágico, 12, 1-96.

Mina Editores. (2001). La Santa Muerte. Mundo esotérico. Magia, ritos y astrología, 135, 28.

Mina editores. (2018). Mina Editores. Recuperado de: https://www.facebook.com/minaeditoresoficial/

Mina Editores. (s.f.). Aromaterapia. Mundo Esotérico. Magia, ritos y astrología, 72

Oraciones a la Santa Muerte. (2018). Oraciones a la Santa Muerte. Recuperado de: http://oracionesalasantamuerte. com/

Perdigón, K. (2008). Una relación simbiótica entre la santa Muerte y el Niño de las suertes. Revista LiminaR. Estudios Sociales y Humanísticos, 6(1), 52-67. https://doi.org/10.29043/liminar.v6i1.266

Perdigón, K. (2017). La Santa Muerte, defensora de los hombres. Instituto Nacional de Antropología e Historia.

Real Academia de la Lengua. (2020). Fagotización. En Diccionario de la lengua española. Recuperado el 4 de Julio de 2020, de https://dle.rae.es/fagocitar

Reina del Cielo. (2013). Muchas Marías, una Madre de Dios. Consultado de: http://www.reinadelcielo.org/muchasmar\%EE\%A2\%B3-una-madre-de-dios/

Reyes, C. (2011). Historia y actualidad del culto a la Santa Muerte. El cotidiano (169), 51-57. https://www.redalyc.org/ pdf/325/32519776006.pdf

Sgarbossa, M., y Giovannini, L. (2018). Martin de Tours, Santo. http://es.catholic.net/op/articulos/31987/martn-de-tourssanto.html\#modal

Virgendemedjugorje (s.f.) Virgen de Medjugorje. Recuperado de: https://www.virgendemedjugorje.org/historia/

Yllescas Illescas, J. A. (2013). La Santa Muerte hoy: imagen personificada, dones e iniciación en el culto. Vita Brevis, (3), 69-82. https://revistas.inah.gob.mx/index.php/vitabrevis/article/view/3224/o

Zecchetto, V. (2011). El persistente impulso a resemantizar. Universitas. Revista de Ciencias Sociales y Humanas. (14), 127142. https://dialnet.unirioja.es/servlet/articulo?codigo=5968252 


\section{AUTORA}

Azul Kikey Castelli Olvera. Dra. En Ciencias Sociales por la Universidad Autónoma del Estado de Hidalgo. Profesora investigadora de la Universidad Autónoma del Estado de Hidalgo. Coordinadora de programas de la Dirección de Fomento a la Lectura. Integrante del Sistema Nacional de Investigadores (SNI), Nivel 1, Profesora con perfil deseable PROPEP. Líneas de investigación: representaciones mediáticas, género, discurso e imagen.

\section{Conflicto de intereses}

La autora informa de ningún conflicto de interés posible.

\section{Financiamiento}

No existió asistencia financiera de partes externas al presente artículo.

\section{Agradecimientos}

$\mathrm{N} / \mathrm{A}$

\section{Sobre el artículo}

Este trabajo se desprende de una investigación preliminar para una ponencia donde se trabajó el tema de la New Age. 